\title{
Analysis of Student Satisfaction on Academic Services ISO 9001: 2008 Certified
}

\author{
Dessi Susanti ${ }^{1}$, Rose Rahmidani ${ }^{2}$, Armiati $^{3}$ \\ ${ }^{1}$ Universitas Negeri Padang, Padang, Indonesia, $\square$ dessisusanti@fe.unp.ac.id \\ ${ }^{2}$ Universitas Negeri Padang, Padang, Indonesia, $\square$ rose_rahmidani @ fe.unp.ac.id \\ ${ }^{3}$ Universitas Negeri Padang, Padang, Indonesia, $\square$ armiati@fe.unp.ac.id
}

\begin{abstract}
The output of this study was a portrait of student satisfaction toward academic services of Faculty of economics, Universitas Negeri Padang, with ISO 9001: 2008 certified. Data was collected by using questionnaires. This study used a quantitative design with survey method. The conclusions of this study were: 1) Student satisfaction with the academic services of the Faculty of Economics, Universitas Negeri Padang, which was measured in five dimensions of service quality, namely tangible, reliability, responsiveness, assurance, empathy, and information system overall in the less satisfactory category, this result based on the number of final gap perceptions and expectations were -1.34, and from less than $60 \%$ of students chose satisfied answers. 2) Criticism and suggestions of students on the academic services of Faculty of Economics, Universitas Negeri Padang were aimed at all dimensions of academic services, namely tangible, reliability, responsiveness, assurance, empathy and information system.
\end{abstract}

Keywords: perceptions, expectations, dimensions of service quality

\section{Introduction}

Educational institutions are public organizations that are demanded to continuously provide quality services, therefore adequate resources are needed in order to continually improve service devices to maximize the existing servant role. The steps that need to be taken by educational institutions to improve these services are to optimize their human resource capabilities and improve facilities and infrastructure that support the smooth running of education services (Tsinidou, M., Gerogiannis, V., \& Fitsilis, P., 2010; Brewer, PD, \& Brewer, KL, 2010; Clements, K., Pawlowski, J., \& Manouselis, N., 2015; Hanifa, G., Sentosa, SU, \& Armiati, A. (2019).

Organizing education should look at service quality. Educational activities are not only oriented towards the final results of the education process, but also through proof of good accountability including quality assurance, quality control, and quality improvement (National Board of Accreditation for Higher Education, 2015; Thune, C., 2017)

The attention of the university to the quality of service and student satisfaction is a must in managing higher education. Universities must be able to provide the best service for their consumers (Saggaf, MS, Aras, M., Akib, H., 2018; Michael, RD, et al (2018). The increasingly fierce competition conditions in the education sector today force every college or provider of higher education to be able to provide the best and different service from the rivals. This is intended to win the competition.

Universitas Negeri Padang as a university with Public Service Agency referred Badan Layan Umum $(B L U)$ is an institution within the Government that is formed to provide services to the community in the form of the supply of goods and / or services sold without prioritizing seeking profits and in carrying out its activities based on the principles of efficiency and productivity. Universitas Negeri Padang needs to continuously improve the quality of services provided to all parties. This is important in order to realize the satisfaction for service users, which has an impact on winning the competition. Therefore all parties involved in managing the university including within the faculties, departments and study programs must be able to provide qualified services that can meet the needs of students so that they want to recommend Universitas Negeri Padang as a chosen college to continue their education. 
The real condition, Universitas Negeri Padang, exactly Faculty of Economics, there are indications of student dissatisfaction with academic services. This is important for further investigation because if there is not followed up of it is not impossible that this indication of dissatisfaction will ultimately have the effect of lowering the image of Universitas Negeri Padang and certainly weakening the competitiveness of Universitas Negeri Padang in the education market.

The Faculty of Economics, Universitas Negeri Padang has A accreditation status with ISO 9001: 2008 certified until now. The status should immediately provide a positive impact on student satisfaction with academic services. And usually, the positive impact is in the form of satisfaction, not vice versa. This study analyzed the satisfaction of the Faculty of Economics students at Universitas Negeri Padang for academic services that are ISO 9001: 2008 certified.

The questions in this study are 1) How is student satisfaction with the academic services of the Faculty of Economics, Universitas Negeri Padang, which is ISO 9001: 2008 certified and 2) How are the criticisms and suggestions of students for the academic services of the Faculty of Economics, Universitas Negeri Padang that is ISO 9001: 2008 certified.

The quality of service in universities by providing the application of standardized quality services will have an impact on student satisfaction (Mulyawan and Sidharta, 2013). Safiullin., Et all (2017) in his research succeeded in proving that customer satisfaction is determined by customer ratings of the quality of provided services. Ali \& Raza (2017) customer satisfaction is influenced by expectations, perceptions of performance, and assessment of the performance of products or services consumed. There is a strong positive correlation between perceptions of performance towards customer satisfaction (Kasiri, et al 2017; Saini \& Singh, 2018).

Napitupulu., Et all (2018) states that customer satisfaction or dissatisfaction is the customer's response to the evaluation of the perceived incompatibility between the previous expectations and the actual performance of the product after its use. Parsons (2017) examines consumer satisfaction which shows a positive influence between previous buying experiences on satisfaction levels.

Based on these studies, customer satisfaction can be formed from 3 indicators, namely the suitability of expectations, perceptions of performance and customer ratings. So that the conclusion is drawn the difference between expectations and performance or perceived results. When associated with the context of student satisfaction research, it can be defined that student satisfaction as a result of a comparison between expectations and performance/quality of services obtained in the lecture process in college.

Some research results conclude, that quality is a number of features and characteristics of products or services that have the ability to satisfy customer needs (Ellis, 2018; Pansari, A., \& Kumar, V. (2017). Research results are related to several types services successfully identified five main factors/dimensions that determine service quality (SERVQUAL), such as 1) reliability, is the ability to provide promised services promptly, accurately and satisfactorily, 2) responsiveness, is the desire of staff to assist customers and provide responsive services, 3) assurance includes knowledge, ability, politeness, and trustworthiness of staff, free from danger, risk or doubt, 4) empathy includes ease in making relations, good communication, personal attention, and understanding customer needs, and 5) tangibles (physical evidence) including physical facilities, equipment, teaching staff, and means of communication. This study uses SERVQUAL as a measurement of academic service quality performance at the Faculty of Economics, Universitas Negeri Padang.

\section{Methods}

This study uses a quantitative research design with survey methods and research sites at the Faculty of Economics, Universitas Negeri Padang. The number of sample in this study based on Roscoe (1975), with 346 people. Distribution of departmental samples using proportional random sampling technique.

Data was collected using 2 kinds of questionnaires, such as 1) Closed questionnaire, containing statements to measure students' perceptions and expectations of academic services, by providing answer choices to students who were already available with interval scale 1 to 5,2 ) Open 
questionnaire, containing questions about student criticism and suggestions for academic services at the Faculty of Economics, Universitas Negeri Padang.

Analysis of the data used is: 1) Quantitative analysis, which is using the Service Quality Gaps Model according to Parasuraman, Zeithaml, and Berry. To measure the satisfaction of students of Economics Faculty at Universitas Negeri Padang, student perceptions were compared with expectations. Differences in perceptions and expectations on these measurements (called gaps) are averaged, then weighted to obtain a measure called Final Gap, 2) Qualitative analysis, related to criticism from students of the Faculty of Economics, Universitas Negeri Padang for academic services that are ISO 9001:2008 certified.

\section{Results and Discussion}

The results of the study are presented in the table below:

\section{Student Satisfaction}

Student satisfaction is seen from the comparison of student perceptions with student expectations of the quality of service of Faculty of Economics, Universitas Negeri Padang (Final Gap). The results of the collected data can be distributed as follows:

Table 1 Quality of Academic Services Faculty of Economics, Universitas Negeri Padang

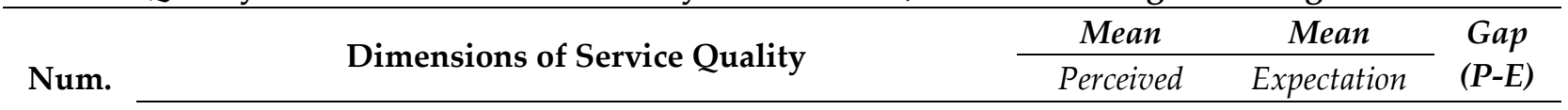

a) Physical Evidence (Tangibles)

\begin{tabular}{llccc}
\hline 1 & Clean and neatly arranged lecture room & 3.52 & 4.67 & -1.15 \\
\hline 2 & Lecture rooms cool and comfortable & 3.68 & 4.69 & -1.01 \\
\hline 3 & Learning facilities available in the lecture room. & 3.49 & 4.63 & -1.14 \\
\hline 4 & Faculty of Economics UNP has a complete library & 3.2 & 4.64 & -1.44 \\
\hline 5 & $\begin{array}{l}\text { Laboratory of the Faculty of Economics UNP relevant to } \\
\text { scientific needs for students (computers and others) }\end{array}$ & 3.38 & 4.6 & -1.22 \\
\hline 6 & $\begin{array}{l}\text { Availability of reference books in the library of the } \\
\text { Faculty of Economics UNP }\end{array}$ & 3.14 & 4.57 & -1.43 \\
\hline 7 & Availability of adequate and clean washroom facilities & 3.16 & 4.59 & -1.43 \\
\hline 8 & $\begin{array}{l}\text { Religion facilities that can be used by students at the } \\
\text { Faculty of Economics, UNP }\end{array}$ & 3.17 & 4.7 & -1.53 \\
\cline { 2 - 3 } & $\begin{array}{l}\text { Final Gap Average Dimensions of Physical Evidence } \\
\text { (Tangibles) }\end{array}$ & 3.34 & 4.64 & \\
\hline
\end{tabular}

b) Reliability Dimensions ( reliability of lecturers, academic staff)

\begin{tabular}{llccc}
\hline 1 & Clarity of lecture material given by the lecturer & 3.31 & 4.62 & -1.31 \\
\hline 2 & Time provided for discussion and question and answer & 3.34 & 4.55 & -1.21 \\
\hline 3 & $\begin{array}{l}\text { Supplementary teaching materials (handouts, modules, } \\
\text { etc.) given to students to complete lecture material }\end{array}$ & 3.32 & 4.59 & -1.27 \\
\hline 4 & $\begin{array}{l}\text { Lecturers in returning test results/assignments with } \\
\text { objective values }\end{array}$ & 3.01 & 4.55 & -1.54 \\
\hline 5 & Lecturers arrive on time & 3.25 & 4.58 & -1.33 \\
\hline 6 & lecturers qualify according to their field of expertise & 3.51 & 4.64 & -1.13 \\
\hline 7 & Lecture Program Units made by lecturers & 3.33 & 4.55 & -1.22 \\
\hline 8 & $\begin{array}{l}\text { The bility of academic staff to serve student } \\
\text { administration }\end{array}$ & 3.24 & 4.6 & -1.36 \\
\hline 9 & $\begin{array}{l}\text { Quality of academic staff services to meet student } \\
\text { interests }\end{array}$ & 3.28 & 4.6 & -1.32 \\
\cline { 2 - 4 } & $\begin{array}{l}\text { Final Gap Average Reliability Dimensions (lecturer } \\
\text { reliability, academic staff) }\end{array}$ & 3.3 & 4.59 & -1.29 \\
\hline
\end{tabular}


Table Cont...

\begin{tabular}{|c|c|c|c|c|}
\hline & c) Dimensions of Responsiveness (Response Attitude) & & & \\
\hline 1 & $\begin{array}{l}\text { Faculty of Economics UNP appoints PA lecturers } \\
\text { (Academic Advisors) whose function is for student } \\
\text { consultation and sharing }\end{array}$ & 3.58 & 4.66 & -1.08 \\
\hline 2 & $\begin{array}{l}\text { Faculty of Economics UNP provides scholarships for } \\
\text { underprivileged students }\end{array}$ & 3.41 & 4.69 & -1.28 \\
\hline 3 & $\begin{array}{l}\text { Faculty of Economics UNP helps students face academic } \\
\text { problems }\end{array}$ & 3.2 & 4.62 & -1.42 \\
\hline \multirow[t]{3}{*}{4} & $\begin{array}{l}\text { The Faculty of Economics leaders of UNP and their staff } \\
\text { provide time for parents to consult }\end{array}$ & 2.92 & 4.58 & -1.66 \\
\hline & $\begin{array}{l}\text { Final Gap average Dimensions of Responsiveness } \\
\text { (Response Attitude) }\end{array}$ & 3.28 & 4.64 & -1.36 \\
\hline & d) Dimensions of Assurance (Treating students) & & & \\
\hline 1 & $\begin{array}{l}\text { The academic administrative staff of the UNP Faculty of } \\
\text { Economics is polite in providing services }\end{array}$ & 3.18 & 4.61 & -1.43 \\
\hline 2 & $\begin{array}{l}\text { Student problems/complaints are handled by the UNP } \\
\text { Faculty of Economics through PA lecturers (Academic } \\
\text { Advisors) }\end{array}$ & 3.28 & 4,671 & $-1,391$ \\
\hline 3 & $\begin{array}{l}\text { Every job/assignment is always returned by } \\
\text { lecturers to students }\end{array}$ & 2.95 & 4,561 & -1611 \\
\hline 4 & $\begin{array}{l}\text { Time used effectively by the lecturers in teaching } \\
\text { process }\end{array}$ & 3:37 & 4647 & -1277 \\
\hline \multirow[t]{3}{*}{5} & $\begin{array}{l}\text { Penalties for students who violate rules set of Faculty of } \\
\text { Economics UNP and applies to all students without } \\
\text { exception }\end{array}$ & $3: 44$ & 4636 & -1196 \\
\hline & $\begin{array}{l}\text { Final Gap average of Assurance Dimension (Treating } \\
\text { Students) }\end{array}$ & 3.25 & 4.625 & -1.375 \\
\hline & $\begin{array}{l}\text { e) Dimensions of Empathy (Understanding of Student } \\
\text { Interests) }\end{array}$ & & & \\
\hline 1 & $\begin{array}{l}\text { Concerning of UNP Faculty of Economics in } \\
\text { understanding student interests and difficulties }\end{array}$ & 3.14 & 4.63 & -1.49 \\
\hline 2 & $\begin{array}{l}\text { Faculty of Economics UNP monitors the progress of } \\
\text { students through Academic Advisor lecturers }\end{array}$ & 3.2 & 4.57 & -1.37 \\
\hline 3 & $\begin{array}{l}\text { Lecturers are willing to help students who have } \\
\text { difficulty in academic fields/subjects }\end{array}$ & 3.3 & 4.58 & -1.28 \\
\hline 4 & Lecturers are open, cooperative with students & 3.32 & 4.65 & -1.33 \\
\hline \multirow[t]{3}{*}{5} & $\begin{array}{l}\text { Faculty of Economics UNP seeks to understand student } \\
\text { interests and talents and strives to develop them }\end{array}$ & 3.32 & 4.63 & -1.31 \\
\hline & $\begin{array}{l}\text { Final Gap Average Empathy Dimensions } \\
\text { (Understanding of Student Interests) }\end{array}$ & 3.26 & 4.61 & -1.35 \\
\hline & $\begin{array}{l}\text { f) Dimensions of Information System (Student } \\
\text { information system) }\end{array}$ & & & \\
\hline 1 & $\begin{array}{l}\text { Faculty of Economics UNP provides lecture system } \\
\text { information in the form of lecture guidebook }\end{array}$ & 3.38 & 4.61 & -1.23 \\
\hline 2 & $\begin{array}{l}\text { Faculty of Economics UNP provides academic } \\
\text { information and non-academic services in the form of } \\
\text { website (online) }\end{array}$ & 3.53 & 4.63 & -1.1 \\
\hline
\end{tabular}


Table Cont...

\begin{tabular}{llccc}
\hline 3 & $\begin{array}{l}\text { Faculty of Economics UNP openly provide information } \\
\text { and services both academically and non-academically }\end{array}$ & 3.47 & 4.6 & -1.13 \\
\hline 4 & $\begin{array}{l}\text { Faculty of Economics UNP opens a complaint service } \\
\text { for students who have problems }\end{array}$ & 3.07 & 4.6 & -1.53 \\
\hline 5 & $\begin{array}{l}\text { Faculty of Economics UNP seeks to respond positively } \\
\text { to every student complaint }\end{array}$ & 3.16 & 4.6 & -1.44 \\
\hline 6 & $\begin{array}{l}\text { Faculty of Economics UNP strives transparent in } \\
\text { explaining the use of student funds }\end{array}$ & 2.99 & 4.62 & -1.63 \\
\cline { 2 - 6 } & Final Gap Average Information System Dimensions & 3.27 & $\mathbf{4 . 6 1}$ & $\mathbf{- 1 . 3 4}$ \\
\cline { 2 - 5 } & Final Gap Average 6 Dimensions of service quality & $\mathbf{3 . 2 8}$ & $\mathbf{4 . 6 2}$ & $\mathbf{- 1 . 3 4}$ \\
\hline
\end{tabular}

Source: Research data processed in 2018

From the six academic service quality dimensions of the Faculty of Economics, Universitas Negeri Padang, shows that the average score of student satisfaction on academic services (final gap) is -1.34 . If referring to the parameters proposed by Parasuraman (1998), the final gap interpretation, the following criteria are obtained:
$0-(-0.5)$
: Healthy company, healthy market leaders Existing in the world
$(-0.5)-(-1)$
Company is quite good at satisfying customers
$(-1)-(-1.5)$
Company has a company average value in the world
$(-1.5)-(-2)$
Companies are below the average company
-2 and above : Survival of companies needs to be questioned

Based on the above criteria, the Faculty of Economics in academic services in the six dimensions of service quality has the average ability to satisfy students. Of the six dimensions of service quality that get the highest scores are dimensions of reliability (reliability of lecturers, academic staff) that is equal to -1.29 (This dimension has the average ability to satisfy students) and the lowest is the dimension of Assurance (treatment for students) that is equal to - 1,375 (This dimension also has average ability to satisfy students).

The dimension of reliability ( reliability of the lecturer, academic staff) is a dimension that has the smallest gap of -1.29 , it means that between expectations and reality obtained by students for the academic services of the Faculty of Economics, Universitas Negeri Padang has almost matched. The Dimension of Assurance (Treatment for Students) is the dimension that has the largest gap of $-1,611$, it means that between expectations and reality obtained by students for the academic services of the Faculty of Economics, Universitas Negeri Padang is still far from appropriate.

\section{Students Criticism and Suggestions for academic services at the Faculty of Economics, Universitas Negeri Padang}

This research uses descriptive data to collect critical data and student suggestions through an open essay questionnaire, to be able to explore what is expected by students in order to improve academic services at Faculty of Economics, Universitas Negeri Padang. The criticisms and suggestions from students for academic services, Faculty of Economics, Universitas Negeri Padang, are presented as follows:

1) Student Criticism and Suggestions for Academic Services, Faculty of Economics, Universitas Negeri Padang Dimension of Physical Evidence (Tangibles)
a) It is recommended to smooth the wifi network prioritizing
b) The cleanliness of all toilets especially the $1^{\text {st }}$ floor
c) It should have room deodorizer, handshop and tissue in toilet
d) It is recommended that the availability of waiting seats for students is sufficient. 
e) It is recommended that faculty leaders urge all academics to maintain class and toilet hygiene.

f) It is recommended that complete reference books in the library accommodate student needs based on their respective majors

2) Student Criticism and suggestion for Academic Services Faculty of Economics Universitas Negeri Padang Reliability Dimensions (reliability of lecturers, academic staff)

a) It is recommended that the lecturers are objective and transparent in conducting an assessment of learning outcomes

b) It is recommended that lecturers come on time

3) Student Critics and Suggestions for Academic Services Faculty of Economics, Universitas Negeri Padang Responsiveness dimensions.

a) Faculty leaders should pay attention to underprivileged students to get a scholarship

b) It is best for administration/correspondence services to quickly complete the process

4) Student Criticism and Suggestions for Academic Services Faculty of Economics, Universitas Negeri Padang Assurance Dimension (treating Student)

a) Lecturers should apply $3 S$ senyum, salam, sapa (smiles and greetings)

b) Administration staff and library staff should be gracious in providing services

c) It is recommended that all lecturers return the assignments to the students after being assessed

5) Student Criticism and Suggestions for Academic Services Faculty of Economics, Universitas Negeri Padang of Empathy Dimensions (understanding the interests of students)

a) Administrative staff should accept the students' suggestions

6) Student Criticism and Suggestions for Academic Services Faculty of Economics, Universitas Negeri Padang Dimension of Information System (Student information system)

a) It is better for academic and student information to use a digital board to be more efficient.

b) It is better than at the beginning of each semester there is no clashed-class schedule

Next Parasuraman (1998) states that companies are categorized as satisfying customers if the customer satisfaction is above $60 \%$ (choosing a satisfying answer more than $60 \%$ of customers). The results of this study, where the percentage of students who responded satisfactorily to the top (giving grades 4 and 5 from the Likert scale) in each dimension and in each indicator were below $60 \%$, it means that the Faculty of Economics, Universitas Negeri Padang in providing academic services were categorized as less satisfying its students. So that the criticisms and suggestions of students for the academic services of the Faculty of Economics, Universitas Negeri Padang are aimed at all dimensions of existing services.

ISO 9001: 2008 Certificate was obtained by the Faculty of Economics, Universitas Negeri Padang since 2012, and continues to be extended. ISO 9001: 2008 clauses include: conducting customer satisfaction surveys, at certain intervals, customer satisfaction surveys must be conducted to determine customer perceptions of the quality of products (goods/services) provided by the organization. Among the most dominant principles of ISO 9001: 2008 is the principle of continuous improvement. That is, the organization must not be satisfied with the achievement of results that are already in line with the target but continuously increase the target every year. Unattainable targets must be analyzed and evaluated to determine the root cause and corrective actions. Likewise, the problems that occur need to be recorded and controlled, analyzed, evaluated and given corrective actions. Any situation that is considered to be a potential nonconformity in the future must be analyzed and given precautionary measures.

One of the commitments of the Faculty of Economics Universitas Negeri Padang is to hold a qualified Higher Education. The more qualified the implementation of education the higher the satisfaction of students as customers. ISO 9001: 2008 has the role of continuously evaluating student satisfaction, of course, this implicitly implies how the quality of services provided to students. 
Even so, it needs more effort for the Faculty of Economics, Universitas Negeri Padang to improve the quality of services provided, to be able to improve its ability to satisfy students as customers.

\section{Conclusions}

The conclusions of this study are the student satisfaction with the academic services of the Faculty of Economics, Universitas Negeri Padang, measured in six dimensions, namely tangible, reliability, responsiveness, assurance, empathy, and the information system overall is not satisfying the students, this is seen from final existing gap, which is equal to -1.34 , and from student answers where less than $60 \%$ choose satisfied answers.For students' criticism and suggestions on academic services of the Faculty of Economics, Universitas Negeri Padang, it is intended for all dimensions of academic services, such as tangible, reliability, responsiveness, assurance, empathy and information system.

\section{References}

Ali, M., \& Raza, S. A. (2017). Service quality perception and customer satisfaction in Islamic banks of Pakistan: the modified SERVQUAL model. Total Quality Management \& Business Excellence, 28(5-6), 559-577.

Brewer, P. D., \& Brewer, K. L. (2010). Knowledge management, human resource management, and higher education: A theoretical model. Journal of Education for Business, 85(6), 330-335.

Clements, K., Pawlowski, J., \& Manouselis, N. (2015). Open educational resources repositories literature review-Towards a comprehensive quality approaches framework. Computers in human behavior, 51, 1098-1106.

Ellis, R. (2018). Quality assurance for university teaching: Issues and approaches. In Handbook of Quality Assurance for University Teaching (pp. 21-36). Routledge.

Hanifa, G., Sentosa, S. U., \& Armiati, A. (2019). Pengaruh Persepsi Tentang Sarana Prasarana Perkuliahan Dan Pelayanan Administrasi Akademik Terhadap Kepuasan Mahasiswa (Studi Pada Mahasiswa Jurusan Pendidikan Ekonomi Fakultas Ekonomi Universitas Negeri Padang). Jurnal Ecogen, 1(4), 837-846.

Kasiri, L. A., Cheng, K. T. G., Sambasivan, M., \& Sidin, S. M. (2017). Integration of standardization and customization: Impact on service quality, customer satisfaction, and loyalty. Journal of Retailing and Consumer Services, 35, 91-97.

Michael, R. D., Webster, C. A., Egan, C. A., Stewart, G., Nilges, L., Brian, A., ... \& Vazou, S. (2018). Viability of university service learning to support movement integration in elementary classrooms: Perspectives of teachers, university students, and course instructors. Teaching and Teacher Education, 72, 122-132.

Mundiri, A. (2017). Organizational Culture Base on Total Quality Management In Islamic Educational Institution. ADRI International Journal of Islamic Studies and Social Sciences, 1(1).

Mulyawan, A., \& Sidharta, I. .2013. Analisis Deskriptif Pemasaran Jasa Di STMIK Mardira Indonesia Bandung. Jurnal Computech \& Bisnis, 7(1), 42-55

Napitupulu, D., Rahim, R., Abdullah, D., Setiawan, M. I., Abdillah, L. A., Ahmar, A. S., ... \& Pranolo, A. (2018, January). Analysis of Student Satisfaction Toward Quality of Service Facility. In Journal of Physics: Conference Series (Vol. 954, No. 1, p. 012019). IOP Publishing.

Pansari, A., \& Kumar, V. (2017). Customer engagement: the construct, antecedents, and consequences. Journal of the Academy of Marketing Science, 45(3), 294-311.

Parsons, C. (2017). Quality improvement in education: case studies in schools, colleges and universities. Routledge.

Parasuraman A, Zheitmal VA, Berry LL. SERVQUAL: a multiple- item scale for measuring consumer perceptions of service quality. J Retailing. 1998;64(1):12-40.

Roscoe, J.T. (1975) Fundamental Research Statistics for the Behavioural Sciences, $2^{\text {nd }}$ edition. New York: Holt Rinehart \& Winston.

Saggaf, M. S., Aras, M., Akib, H., Salam, R., Baharuddin, A., \& Kasmita, M. (2018). The Quality Analysis of Academic Services Based on Importance Performance Analysis (IPA). 
Safiullin, L. N., Gafurov, I. R., Bagautdinova, N. G., \& Safiullin, N. Z. (2017). Influence of quality of the goods on satisfactions of consumers. GSTF Journal on Business Review (GBR), 2(2).

Saini, S., \& Singh, R. (2018). Service Quality Assessment of Utility Company in Haryana using SERVQUAL Model. Asian Journal of Management, 9(1), 702-708.

Tsinidou, M., Gerogiannis, V., \& Fitsilis, P. (2010). Evaluation of the factors that determine quality in higher education: an empirical study. Quality Assurance in education, 18(3), 227-244.

Thune, C. (2017). Quality assurance of higher education in Denmark. In Global Perspectives on Quality in Higher Education (pp. 82-102). Routledge. 